\title{
Checking Out Facebook.com: The Impact of a Digital Trend on Academic Libraries
}

While the burgeoning trend in online social networks has gained much attention from the media, few studies in library science have yet to address the topic in depth. This article reports on a survey of 126 academic librarians concerning their perspectives toward Facebook.com, an online network for students. Findings suggest that librarians are overwhelmingly aware of the "Facebook phenomenon." Those who are most enthusiastic about the potential of online social networking suggested ideas for using Facebook to promote library services and events. Few individuals reported problems or distractions as a result of patrons accessing Facebook in the library. When problems have arisen, strict regulation of access to the site seems unfavorable. While some librarians were excited about the possibilities of Facebook, the majority surveyed appeared to consider Facebook outside the purview of professional librarianship.

D uring the fall of 2005, librarians noticed something unusual going on in the Houston Cole Library (HCL) at Jacksonville State University (JSU). Students were coming into the library in droves. Patrons waited in lines with photos to use the public-access scanner (a stack of discarded pictures quickly grew). Library traffic was noticeably busier than usual and the computer lab was constantly full, as were the public-access terminals. The hubbub seemed to center around one particular Web site. Once students found available computers, they were likely to stay glued to them for long stretches of time, mesmerized and lost in what was later determined to be none other than "Facebook addiction." This addiction was all the more obvious the day the Internet was down. Withdrawal was severe. Soon after the librarians noticed this curious behavior, an article in the Chanticleer, the campus newspaper for JSU, dispelled the mystery surrounding the Web-site brouhaha. A campus reporter broke the exciting news to the JSU community that "after months of waiting and requests from across the country, it's finally here. JSU is officially on the Facebook." ${ }^{1}$ The library suddenly became a popular hangout for students in search of computers to access Facebook.

Laurie Charnigo (charnigo@jsu.edu) is an Education Librarian and Paula Barnett-Ellis (pbarnett@ jsu.edu) is a Health, Science, and Nursing Librarian at the Houston Cole Library, Jacksonville State University, Alabama.
Apparently JSU jumped on the bandwagon relatively late. The Facebook craze had already spread throughout other colleges and universities since the Web site was founded in February 2004 by Mark Zuckerberg, a former student at Harvard University. The creators of Facebook vaguely define the site as "a social utility that connects you with the people around you." 2 Although originally created to allow students to search for other students at colleges and universities, the site has expanded to allow individuals to connect in high schools, companies, and within regions. Recently, Zuckerberg has also announced plans to expand the network to military bases. ${ }^{3}$ Currently, students and alumni in more than 2,200 colleges and universities communicate, connect with other students, and catch up with past high school classmates daily through the network. Students who may never physically meet on campus (a rather serendipitous occurrence in nature) have the opportunity to connect through Facebook. Establishing virtual identities by creating profiles on the site, students post photographs, descriptions of academic and personal interests such as academic majors, campus organizations of which they are members, political orientation, favorite authors and musicians, and any other information they wish to share about themselves. Facebook's search engine allows users to search for students, faculty, and staff with similar interests by keyword. It would be hard to gauge how many of these students actually meet in person after connecting through Facebook. The authors of this study have heard students mention that either they or their friends have made dates with other students on campus through Facebook. Many of the "friends" Facebook users first add when they initially establish their accounts are the ones they are already acquainted with in the physical world.

When Facebook made its debut at ISU, it had become the "ninth most highly trafficked Web site in the U.S." One source estimated that 85 percent of college students whose institutions are registered in Facebook's directory have created personal profiles on the site. ${ }^{5}$ Membership for the university network requires a university e-mail address, and an institution cannot be registered in the directory unless a significant number of students request that the school be added. Currently, more than nine million people are registered on Facebook. ${ }^{6}$

Soon after JSU was registered on Facebook's directory, librarians began to receive questions regarding use of the scanner and requests for help uploading pictures to Facebook profiles. Students seemed surprisingly open about showing librarians their profiles, which usually contained more information than the librarians wanted to know. However, not all students were enthusiastic about Facebook. Complaints began to surface from students awaiting access to computers for academic work while classmates "tied up" computers on Facebook. Some students complained about the distraction Facebook caused 
in the library's computer lab, a complaint that eventually reached the president of JSU. Currently, the administration at JSU has decided to block access to Facebook in the computer labs on campus, including the lab in the library. Opinions of faculty and staff in the library about Facebook vary. Some librarians scoff at this new trend, viewing the site primarily as just another dating service. Others have created their own Facebook accounts just to see how it works, to connect with students, and to keep up with the latest Internet fad. ${ }^{7}$

\section{Study rationale}

Prompted by the issues that have arisen at HCL as a result of heavy patron use of Facebook, the authors surveyed academic librarians throughout the United States to find out what impact, if any, the site has had on other libraries. The authors sought information about the practical effect Facebook has had on libraries, as well as librarians' perspectives, perceived roles associated with, and awareness of Internet social trends and their place in the library. Online social networking, like e-mail and instant messaging, is emerging as a new method of communication. Recently, the librarians have heard Facebook being used as a verb (e.g., "I'll Facebook you"). Few would probably disagree that making social connections and friends (and Facebook revolves around connecting friends) is an important aspect of the campus experience. Much of the attraction students and alumni have toward college yearbooks (housed in the library) stems from the same fascination that viewing photos, student profiles, and searching for past and present classmates on Facebook inspires. Emphasis in this study centers on librarians' awareness of, experimentation with, and attitudes towards Facebook and whether or not they have created policies to regulate or block access to the site on public-access computers.

However trendy an individual Web site such as Facebook may appear, online social networking, a category Facebook falls within, has become a new subject of inquiry to marketing professionals, sociologists, communication scholars, and library and information scientists. Downes defines social networks as a "collection of individuals linked together by a set of relations." ${ }^{8}$ According to Downes, "Social networking Web sites fostering the development of explicit ties between individuals as 'friends' began to appear in 2002." ${ }^{\prime 9}$ Facebook is just one of many popular online social network sites (MySpace, Friendster, Flickr), and survey respondents often asked why questions focused solely on Facebook. The authors decided to investigate it specifically because it is currently the largest online social network targeted for the academic environment.
Librarians are also increasingly exploring the use of what have loosely been referred to as "Internet 2.0" companies and services, such as Facebook, to interact with and reach out to our users in new and creative ways. The term Internet 2.0 was coined by O'Reilly Media to refer to Internet services such as blogs, wikis, online social networking sites, and types of networks that allow users the ability to interact and provide feedback. O'Reilly lists the core competencies that define Internet 2.0 services. One of these competencies, which might be of particular interest to librarians, is that Internet 2.0 services must "trust the users" as "co-developers." ${ }^{10}$ As librarians struggle to develop innovative ways to reach users beyond library walls, it seems logical to observe online services, such as Facebook and MySpace, which appeal to a huge portion of our clientele.

From a purely evaluative standpoint of the site as a database, the authors were impressed by several of the search features offered in Facebook. Graph-theory algorithms and other advanced network technology are used to process connections. ${ }^{11}$ Some of the more interesting search options available in Facebook include the ability to:

- search for students by course field, class number, or section;

- search for students in a particular major;

- search for students in a particular student organization or club;

- create "groups" for student organizations, clubs, or other students with common interests;

- post announcements about campus or organization events;

- search specifically for alumni; and

- block or limit who may view profiles, providing users with built-in privacy protection if the user so wishes.

Since the authors finished the study, the site has added a News Feed and a Mini Feed, features that allow users to keep track of their friends' notes, messages, profile changes, friend connections, and group events. In response to negative feedback about the News Feeds and Mini Feeds by users who felt their privacy was being violated, Facebook's administrators created a way for users to turn off or limit information displayed in the feeds. The addition of this technology, however, provides a sophisticated level of connectivity that is a benefit to users who like to keep abreast of the latest happenings in their network of friends and groups. The Pulse, another feature on the site, keeps daily track of popular interests (e.g., favorite books) and member demographics (number of members, political orientation) and compares them with overall Facebook member averages. The authors were pleasantly surprised to discover that the Beatles and Led Zeppelin, beloved bands of the baby boomers, 
continue to live on in the hearts of today's students. These groups were ranked in the top ten favorite bands by students at JSU. As of October 2006, the top campaign issues expressed by Facebook users were: reducing the drinking age to eighteen (go figure) and legalization for same-sex marriage. Arguably, much of the information provided by Facebook is not academic in nature. However, an evaluation or review of Facebook might provide useful information to instruction librarians and database vendors regarding interface design and search capabilities that appeal to students. Provitera-McGlynn suggests that facilitating learning among millennials, who "represent 70 to 80 million people" born after 1992 (a large percentage of Facebook members) involves understanding how they interact and communicate. ${ }^{12}$ Awareness of students' cultural and social interests, and how they interact online, may help older generations of academic librarians better connect with their constituents.

\section{The literature on online social networks}

Although social networks have been the subject of study by sociologists for years and social network theories have been established to describe how these networks function, the study of online social networks has received little attention from the scholarly community. In 1997, Garton, Haythornthwaite, and Wellman were among the first to describe a method, social network analysis, for studying online social networks. ${ }^{13}$ Their work was published years before online social networks similar to Facebook evolved. Currently, the literature on these networks is predominantly limited to popular news publications, business magazines, occasional blurbs in library science and communications journals, and numerous student newspapers. ${ }^{14}$

Privacy issues and concerns about sexual predators lurking on Facebook and similar sites have been the focus of most articles. In the Chronicle of Higher Education, Read details numerous arrests, suspensions, and scholarship withdrawals that have resulted from police and administrators searching for incriminating information students have posted in Facebook. ${ }^{15}$ Read discovered that, because students naively reveal so much information about their activities, some campus police were regularly trolling Facebook, finding it "an invaluable ally in protecting their campuses." 16 Students may feel a false sense of security when they post to Facebook, regarding it as their private space. However, Read warns that "as more and more colleges offer alumni e-mail accounts, and as campus administrators demonstrate more Internet savvy, students are finding that their conversations are playing to a wider audience than they may have anticipated."17 Privacy concerns expressed about Facebook appear to revolve more around surveillance than stalkers. In a Web seminar on issues regarding Facebook use in higher education, Shawn McGuirk, director of Judicial Affairs, Mediation, and Education at Fitchburg State College, Massachusetts, recommends that administrators and others concerned with students posting potentially incriminating, embarrassing, or overtly personal information draft a document similar to the one created by Cornell University's Office of Information Technologies, which advises students on how to safely and responsibly use online social networking sites similar to Facebook. ${ }^{18}$ After pointing out the positive benefits of Facebook and reassuring students that Cornell University is proud of its liberal policy in not monitoring online social networks, the essay, entitled "Thoughts on Facebook," provides poignant advice and examples of privacy issues revolving around Facebook and similar Web sites. ${ }^{19}$ The Golden Rule of this essay states:

Don't say anything about someone else that you would not want said about yourself. And be gentle with yourself too! What might seem fun or spontaneous at 18 , given caching technologies, might prove to be a liability to an on-going sense of your identity over the longer course of history. ${ }^{20}$

A serious concern discussed in this document is the real possibility that potential employers may scan Facebook profiles for the "real skinny" on job candidates. However, unless the employer uses an e-mail issued from the same school as the candidate, he or she is unable to look at the individual's full profile without first requesting permission from the candidate to be added as a "friend." All the employer is able to view is the user's name, school affiliation, and picture (if the user has posted one). Unless the user has posted an inappropriate picture or is applying for a job at the college he or she is attending, the threat of employers snooping for information on potential candidates in Facebook is minimal. The same, however, cannot be said of MySpace, which is much more open and accessible to the public.

Additionally, three pilot research studies have also focused on privacy issues specifically relating to Facebook, including those of Stutzman, Gross and Acquisti, and Govani and Pashley. Results from all three studies revealed strikingly close findings. Individuals who participated in the studies seemed willing to disclose personal information about themselves-such as photos and sometimes even phone numbers and mailing addresses-on Facebook profiles even though students also seemed to be aware that this information was not secure. In a study of fifty Carnegie Mellon University undergraduate users, Govani and Pashley concluded that these users "generally feel comfortable sharing their personal information in a campus environment. Participants said they "had nothing to hide" and "they don't really 
care if other people see their information."21 A separate study of more than four thousand Facebook members at the same institution by Gross and Acquisti echoed these findings. ${ }^{22}$ Comparing identity elements shared by members of Facebook, MySpace, Friendster, and the University of North Carolina Directory, Stutzman discovered that a significant number of users shared personal information about themselves in online social networks, particularly Facebook, which had the highest level of campus participation. ${ }^{23}$ Gross and Acquisti provide a list of explanations suggesting why Facebook members are so open about sharing personal information online. Three explanations that are particularly convincing are that "the perceived benefit of selectively revealing data to strangers may appear larger than the perceived costs of possible privacy invasions"; "relaxed attitudes toward (or lack of interest in) personal privacy"; and "faith in the networking service or trust in its members." 24

In public libraries, concern has primarily centered on teenagers accessing MySpace.com, an online social networking site much larger than Facebook. MySpace, whose membership, unlike Facebook, does not require an edu e-mail address, has a staggering 43 million users, a number that continues to rise. ${ }^{25}$ Julian Aiken, a reference librarian at the New Haven Free Public Library, wrote about the unpopular stance he took when his library decided to ban access to MySpace due to the hysterical hype of media reports exposing the dangers from online predators lurking on the site. ${ }^{26}$ For Aiken, the damage of censorship policies in libraries far outweighs the potential risk of sex crimes. Furthermore, he suggests that there are even educational benefits of MySpace, observing that "[t]eenagers are using MySpace to work on collaborative projects and learn the computer and design skills that are increasingly necessary today."27 What is apparent is that whether Facebook continues to rise in popularity or fizzles out among the college crowd, the next generation of college students, who now constitute the largest percentage of MySpace users, are already solidly entrenched and adept at using online social networks. Librarians in institutions of higher education might need to consider what implications the communication style preferences of these future students could have, if any, on library services.

While most of the academic attention regarding online social networks has centered on privacy concerns, perhaps the business sector has done a more thorough investigation of user behavior and students' growing attraction towards these types of sites. Business magazines have naturally focused on the market potential, growth, and fluctuating popularity of various online social networks. Advertisers and investors have sought ways to capitalize on the exponential growth of these high-traffic sites. Business Week reported that as of October 2005, Facebook .com had 4.2 million members. More than half of those members were between the ages of twelve and twenty- four. ${ }^{28}$ While some portended that the site was losing momentum, as of August 2006, membership on Facebook had expanded beyond eight million. ${ }^{29}$ Marketing experts have closely studied, apparently more so than communication scholars, the behavior of users in online social networks. In a popular business magazine, Hempel and Lehman describe user behavior of the "MySpace Generation": "Although networks are still in their infancy, experts think they're already creating new forms of social behavior that blur the distinctions between online and real-world interactions." 30 The study of user behavior in online social networks, however, has yet to be addressed in length by those outside the field of marketing.

Although evidence of interest in online social networks is apparent in librarian Weblogs and forums (many librarians have created Facebook groups for their libraries), actual literature in the field of library and information science is scarce. ${ }^{31}$ Dvorak questions the lack of interest displayed by the academic community toward online social networks as a focus of scholarly research. Calling on academics to "get to work," he argues "academia, which should be studying these phenomena, is just as out of the loop as anyone over 30." 32 This disconnect is also echoed by Michael J. Bugeja, director of the Greenlee School of Journalism and Communication at Iowa State University, who writes, "While I'd venture to say that most students on any campus are regular visitors to Facebook, many professors and administrators have yet to hear about Facebook, let alone evaluate its impact." 33 The lack of published research articles on these types of networks, however, is understandable given the newness of the technology.

A few members of the academic community have suggested opportunities for using Facebook to communicate with and reach out to students. In a journal specifically geared toward student services in higher education, Shier considers the impact of Facebook on campus community building. ${ }^{34}$ Although she cannot identify an academic purpose for Facebook, she describes how the site can contribute to the academic social life of a campus. Facebook provides students with a virtual campus experience, particularly in colleges where students are commuters or are in distance education. Shier writes, "As the student's definition of community moves beyond the geographic and physical limitations, Facebook.com provides one way for students to find others with common interests, feel as though they are part of a large community, and also find out about others in their classes." 35 Furthermore, Facebook membership extends beyond students to faculty, staff, and alumni. Shier cites examples of professors who used Facebook to connect or communicate with their students, including the president of the University of Iowa and more than one hundred professors at Duke University. Professors who teach online courses make 
themselves seem more human or approachable by establishing Facebook profiles. ${ }^{36}$

Greeting students on their own turf is exactly the direction staff at Washington University's John M. Olin Library decided to take when they hired Web Services librarian Joy Weese Moll to communicate and answer questions through a variety of new technologies, including Facebook. ${ }^{37}$ Brian Mathews, information services librarian at Georgia Institute of Technology, also created a Facebook profile in order to "interact with the students in their natural environment." 38 Mathews decided to experiment with the possibilities of using Facebook as an outreach tool to promote library services to 1,700 students in the School of Mechanical Engineering after he discovered that 1,300 of these students were registered on Facebook. Advising librarians to become proactive in the use of online social networks, Mathews reported that overall, his experience helped him to effectively "expand the goal of promoting the library." ${ }^{39}$ Bill Drew was among the first librarians to create an account and profile for his library, the SUNY Morrisville Library. As of September 2006, nearly one hundred librarians had created profiles or accounts for their libraries on Facebook. One month later, however, the administration at Facebook began shutting down library accounts on the grounds that libraries and institutions were not allowed to represent themselves with profiles as though they were individuals. In response, many of these libraries simply created groups for their libraries, which is completely appropriate, similar to creating a profile, and just as searchable as having an account. The authors of this study created the "Houston Cole Library Users Want Answers!" group, which currently has ninety-one members. Library news and information of interest about the library is announced in the group..$^{40}$ In this study, one trend the authors will try to identify is whether other librarians have considered or are already using Facebook in similar ways that Moll, Mathews, and Drew have explored as avenues for communicating with students or promoting library services.

\section{The survey}

In February 2006, 244 surveys were mailed to reference or public service librarians (when the identity of those persons could be determined). These individuals were chosen from a random sample of the 850 institutions of higher education classified by the Carnegie Classification Listing of Higher Education Institutions as "Master's Colleges and Universities (I and II)" and "Doctoral/ Research Universities (Extensive and Intensive)." 41 The sample size provided a 5.3 percent margin error and a 95 percent confidence level. One hundred twenty-six surveys were completed, providing a response rate of 51 percent. Fifteen survey questions (appendix A) were designed to target three areas of inquiry: awareness of Facebook, practical impact of the site on library services, and perspectives of librarians toward online social networks.

\section{Awareness of Facebook}

A series of questions on the survey queried respondents about their awareness and degree of knowledge about Facebook. The overwhelming majority of librarians were aware of Facebook's existence. Out of 126 librarians, 114 had at least heard of Facebook; 24 were not familiar with the site. As one individual wrote, "I had not heard of Facebook before your survey came, but I checked and our institution is represented in Facebook." Universities registered in Facebook are easily located through a search-by-region on Facebook's home page. Thirty-eight colleges and universities for Alabama (JSU's location) are registered in Facebook. (In comparison, 143 academic institutions in California are listed.) Out of those librarians who had heard of the site, 27 were not sure whether their institutions were registered in Facebook's directory. Sixty survey participants were aware that their institutions were registered in the directory, while fifteen librarians reported that their universities were not registered (figure 1). Several comments at the end of the survey indicated that some of the institutions surveyed did not issue school e-mail accounts, making membership in Facebook impossible for their university. Interestingly, out of the sixty individuals who could claim that their universities were in the directory, 34 percent have created their own personal Facebook accounts and two libraries have individual profiles (figure 2). One individual who established an account on the site wrote, "Personally, I'm a little embarrassed by having an account because it's such a teeny-bopper kind of thing and I'm a little old for it. But it's an interesting cultural phenomenon and academic librarians need to get on the bandwagon with it, if only to better understand their constituents." Another survey respondent with an individual profile on the site reported a group created by his or her institution on Facebook titled "I totally want to have sex in the library." This individual wanted to make it clear, however, that the students-not the librarians-created this group. A particularly helpful participant went so far as to poll the reference colleagues in all nine of the libraries at his/her institution and found that "only a few had even heard of Facebook." That librarians will become increasingly aware of online social networks was the sentiment expressed by another individual who wrote, "Most librarians at my institution are unaware of social software in general, much less Facebook. However, I think this will change in the future as social software is mentioned more often in traditional media (such as television and newspapers)."

According to survey responses, it does not appear 


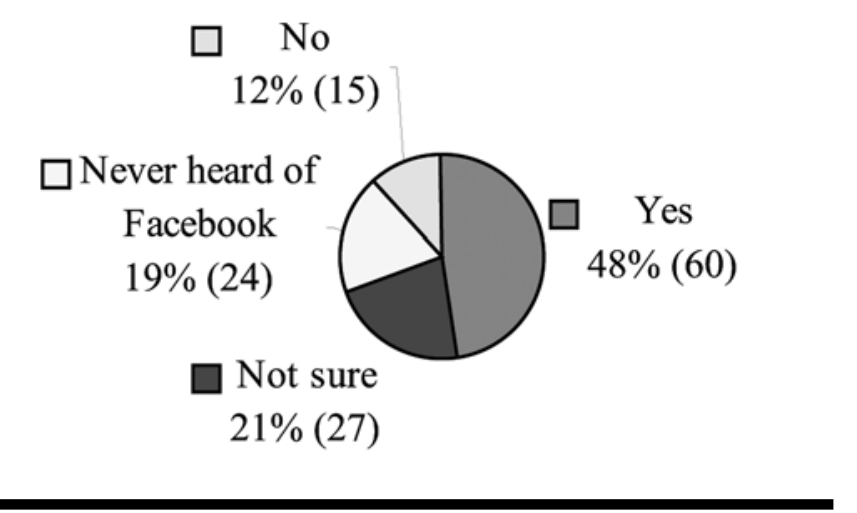

Figure 1. Institutions added to the Facebook directory

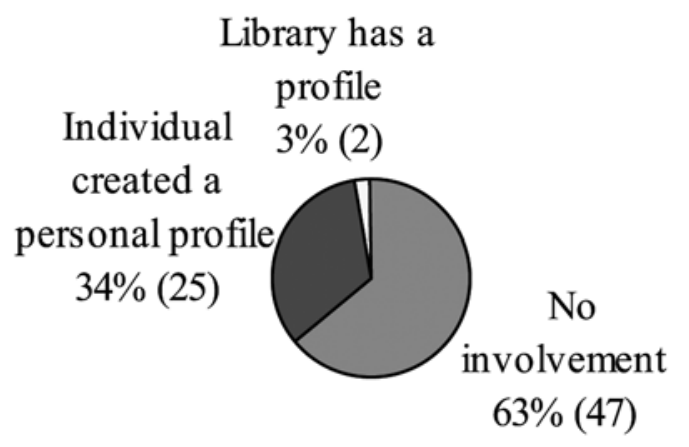

Figure 2. Involvement with Facebook

that use of Facebook by students has been as noticeable or distracting in other libraries as it has been at HCL. When asked to describe their observation of student use of library computers to access Facebook, 56 percent of those surveyed checked "rarely to never." Only 20 percent indicated "most of the time" to "all of the time" (table 1). However, it is important to remember that only sixty individuals could verify that their institutions are registered on Facebook. Through comments, some librarians hinted that "snooping" or keeping mental notes of what students view on library computers is frowned upon. It simply is not our business. "We do not regulate or track student use of computers in the library," wrote one individual. Several librarians noted that students were using Facebook in the libraries, but more so on personal laptops than public-access computers.

\section{Practical impact of Facebook}

Another goal of this study was to find out whether Facebook has had any real impact on library services, such
Table 1. Student use of library computers to access Facebook (based on observation)

\begin{tabular}{lcc}
\hline & Total & Percentage \\
Never & 23 & 32 \\
Rarely & 17 & 24 \\
Some of the time & 17 & 24 \\
All the time & 7 & 10 \\
Most of the time & 7 & 10 \\
\hline
\end{tabular}

as an increase in bandwidth, library traffic, and noise, or in use of public-access computers, scanners, or other equipment. Student complaints about monopolization of computers for use of Facebook led administrators to block the site from computer labs at JSU. Access to Facebook on public-access terminals, however, was not regulated. Survey responses revealed that Facebook has had minimal impact on library services elsewhere. Only one library was forced to develop a policy for specifically addressing computer-use concerns as a result of Facebook use. One individual mailed the sign posted on every computer terminal in the library, which states, "If you are using a computer for games, chat, or other recreational activity, please limit your usage to thirty minutes. Computers are primarily intended for academic use." Another librarian reported that academic computing staff had to shut down access to Facebook on library computers due to bandwidth and access issues. This individual, however, added, "Interestingly, no one has complained to the library staff about its absence!" Given a list of possible effects Facebook may have had on library services and operations, 10 percent of respondents indicated that Facebook has increased patron use of computers. Seven percent agreed that it has increased patron traffic, and only 2 percent reported that the site has created bandwidth problems or slowed down Internet access. Only four individuals received patron complaints about other users "tying up" the computers with Facebook (figure 3).

Since the advent of Facebook, the public scanner has become one of the hottest items in HCL. Librarians at JSU know that use of the scanner has increased tremendously due to Facebook because the scanner used by students to upload photos is attached to a public workstation next to the general reference desk. Students often ask questions about uploading pictures to their Facebook profiles as well as how to edit photos (e.g., resizing and cropping). One survey question asked whether scanner use had increased as a result of Facebook. Of the sixty-two respondents who answered this question (it was indicated that only those libraries that provide public access to scanners should answer the question), 77 percent reported that 


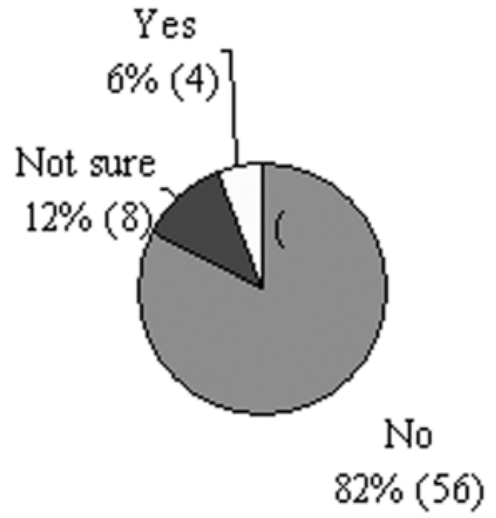

Figure 3. Patron complaints about Facebook

scanner use had not increased. Furthermore, only two librarians have assisted students with the scanner or provided any other type of assistance, for that matter, with Facebook. The assistance the two librarians gave included scanning photographs, editing photos, uploading photos to Facebook profiles, and creating accounts. However, in a separate question, 21 percent of participants agreed that librarians should be responsible for helping students, when needed, with questions about Facebook. No librarian has added additional equipment such as computers or scanners as a result of Facebook. Only one individual reported future plans by his/her library to add additional equipment in the future as a result of heavy use of the site.

\section{Perspectives toward Facebook}

One of the main goals of the study was to obtain a snapshot of the perspectives and attitudes of librarians toward Facebook and online social networks in general. Most of the librarians surveyed were neither enthusiastic nor disdainful of Facebook. A small group of the respondents, however, when given the chance to comment, were extremely positive and excited about the possibilities of online social networking. Twenty-one individuals saw no connection between libraries and Facebook. Sixtyseven librarians were in agreement that computer use for academic purposes should take priority, when needed, over use of Facebook. However, fifty-one respondents indicated that librarians needed to keep up with Internet trends, such as Facebook, even when such trends are not academic in nature (table 2). Out of 126 librarians who completed the survey, only 23 reported that Facebook has generated discussion among library faculty and staff about online social networks. On the other hand, few individuals voiced negative opinions toward Facebook. Only 5 percent of those surveyed indicated that Facebook annoyed faculty and staff. One individual wrote, "I don't like Facebook or most social networking services. They encourage the formation of cliques and keep users from meeting and accepting those who are different than themselves." Comments like this, however, were rare. Although the majority of librarians seemed fairly apathetic toward Facebook, few individuals expressed negative comments toward the site.

Few librarians indicated that Facebook should be addressed or regulated in library policy. Most individuals viewed the site as just another communication tool similar to instant messaging or cell phones. In fact, while most librarians did not express much interest in Facebook, many were quite vocal about not regulating its use. The following comment by one survey participant captures this sentiment: "Attempts to restrict use of Facebook in the library would be futile, in my opinion, in the same way it is now impossible to ban use of USB drives and AIM in academic libraries." While most indi-

Table 2. Access, assistance, and awareness of Facebook and similar trends: perspectives

\begin{tabular}{|c|c|c|}
\hline & Total & Percentage \\
\hline Computer use for academic purposes should take priority, when needed, over use of Facebook. & 67 & 53 \\
\hline Library resources should not be monopolized with use of Facebook. & 35 & 28 \\
\hline There is no connection between libraries and Facebook. & 21 & 17 \\
\hline Student use of Facebook on library computers should not be regulated. & 15 & 12 \\
\hline $\begin{array}{l}\text { Library computers should be available for access to Facebook, but librarians should not feel that it is their } \\
\text { responsibility to assist students with questions regarding the site. }\end{array}$ & 11 & 9 \\
\hline
\end{tabular}

(Respondents were allowed to check any or all responses that applied.) 
viduals agreed that academic use of computers should take priority over recreational use, a polite request that a patron using Facebook allow another student to use the computer for academic purposes, when necessary, appears more preferable than the creation and enforcement of strict policies. As one librarian put it, "I don't want students to see the library as a place where they are 'policed' unnecessarily."

When asked if Facebook serves any academic purpose, 54 percent of those surveyed indicated that it does not, while 34 percent were "not sure." Twelve percent of the librarians identified academic potential or possible benefits of the site (figure 4). The authors were surprised to find that 46 percent of those surveyed were not completely willing to dismiss Facebook as pure recreation. Some librarians found Facebook to be a distraction to academics: "Maybe I'm old fashioned, but when do students find time for this kind of thing? I wonder about the impact of distractions like this on academic pursuits. There's still only twenty-four hours in a day." Another individual asked two students who were using Facebook in the library what they thought of the site and they admitted that it was "frequently a distraction from academic work." For the 34 percent who were not sure whether Facebook has any academic value, there were comments such as "I am continuing to observe and will decide in the future." Academic uses for Facebook included suggestions that it be used as a communication tool for student collaboration in classes (Facebook allows students to search for other students by course and section number). One individual suggested it could be used as an "online study hall," but then wondered if this might lead to plagiarism. Some thought instructors could somehow use Facebook for conducting online discussion forums, with one participant observing "it's 'cooler' than using Blackboard." "Building rapport" with students through a communication medium that many students are comfortable with was another benefit mentioned.

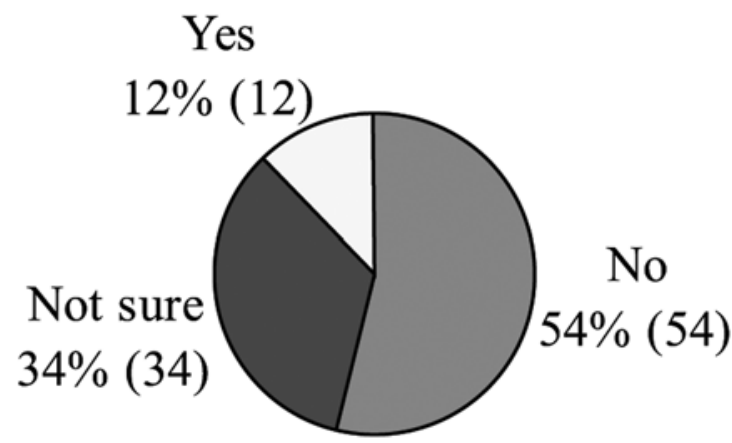

Figure 4. Finds conceivable academic value in Facebook
Respondents who were enthusiastic about Facebook thought it most beneficial as a virtual extension of the campus. Facebook could potentially fill a void where face-to-face connections are absent in online and distance-education classes. Several librarians suggested that Facebook has had a positive influence in fostering collegiate bonds and school spirit. As one individual wrote, "[ $t$ ]he academic environment is not only responsible for scholarly growth, but personal growth as well. This is just one method for students to interact in our highly technological society." Facebook could provide students who are not physically on campus with a means to connect with other students at their institutions who have similar academic and social interests.

Some librarians were so enthusiastic about Facebook that they suggested libraries use the site to promote their services. Using the site to advertise library events and creating online library study groups and book clubs for students were some of the ideas expressed. One librarian wrote: "Facebook (and other social networking sites) can be a way for libraries to market themselves. I haven't seen students using Facebook in an academic manner, but there was a time when librarians frowned on e-mail and AIM too. If it becomes a part of students' lives, we need to welcome it. It's part of welcoming them, too." More librarians, however, felt that Facebook should serve as a space exclusively for students and that librarians, professors, administrators, police, and other uninvited folks should keep out. Furthermore, as one individual noted, it is not "an appropriate venue" for librarians to promote their services.

While the review of literature demonstrates that much has been made of online social networks and privacy issues, the librarians surveyed were not particularly concerned about privacy. Only 19 percent indicated that they were concerned about privacy issues related to Facebook. However, some librarians voiced concerns that many students are ignorant about the risks of posting personal information and photographs on Facebook and do not seem fully aware of the possibility that individuals outside their social sphere might also have reason to access the site. One individual mentioned that the librarians at her institution have begun to emphasize this to students during library instruction sessions on Internet research and evaluation.

\section{Limitations}

Several limitations to this study must be noted when attempting to reach any type of conclusion. Participants who had never heard of Facebook obviously could not answer any questions except that they were not familiar with the site. Some questions required respondents to "guesstimate." Unless librarians have access to their 
institution's Internet usage statistics, it would be hard for them to really know how much bandwidth is being used by students accessing Facebook. Librarians, having been trained in a profession that places a high value on freedom of access, might also be wary of activities that suggest any type of censorship. Therefore, it is conceivable that some of the librarians surveyed do not know whether students are using Facebook in the library because they make a point not to snoop or make note of individual Web sites that students view.

\section{Discussion}

While online education is growing at a rapid rate across the United States, so is the presence of virtual academic social communities. Although Facebook might prove to be a passing fad, it is one of the earliest and largest online social networking communities geared specifically for students in higher education. It represents a new form of communication that connects students socially in an online environment. If online academics have evolved and continue to do so, then it is only natural that online academic social environments, such as Facebook, will continue to evolve as well. While traditionally considered the heart of the campus, one is left to ponder the library's presence in online academic social networks. What role the library will serve in these environments might largely depend on whether librarians are proactive and experimental with this type of technology or whether they simply dismiss it as pure recreation. Emerging technologies for communication should provoke, at the very least, an interest in and knowledge of their presence among library and information science professionals.

This survey found that librarians were overwhelmingly aware of and moderately knowledgeable about Facebook. Some librarians were interested in and fascinated with Facebook, but preferred to study it as outsiders. Others had adopted the technology, but more for the purpose, it would seem, of having a better understanding of today's students and why Facebook (and other online social networking sites) appeals to so many of them. It is apparent from this study that there is a fine line between what now constitutes "academic" activity and "recreational" activity in the library. Sites like Facebook seem to blur this line further and librarians do not seem eager or find it necessary to distinguish between the two unless absolutely pressed (e.g., asking a student to sign out of Facebook when other patrons are waiting to use computers for academic work). One area of attention this study points to is a lack of concern among librarians toward the Internet and privacy issues. Some individuals surveyed suggested that librarians play a larger role in making students aware that people outside their society of friends-namely, administrative or authority figures-have the ability to access the information they post online to social networks.

Participants were most enthusiastic about Facebook's role as a space where students in the same institution can connect and share a common collegiate bond. Librarians who have not yet "checked out" Facebook might consider one individual's description of the site as "just another version of the college yearbook that has become interactive." 42 Among the most cherished books in HCL that document campus life at JSU are the Mimosa Yearbooks. Alumni and students regularly flip through this treasure trove of photographs and memories. No administrator or librarian would dare weed this collection or find its presence irrelevant. While year books archive campus yesteryears, online social networks are dynamically documenting the here and now of campus life and shaping the future of how we communicate. As Casey writes, "Libraries are in the habit of providing the same services and the same programs to the same groups. We grow comfortable with our provision and we fail to change." 42 By exploring popular new types of Internet services such as Facebook instead of quickly dismissing them as irrelevant to librarianship, we might learn new ways to reach out and communicate better with a larger segment of our users.

\section{Acknowledgements}

The authors would like to acknowledge Stephanie M. Purcell, student worker at the Houston Cole Library, for her excellent editing suggestions and insight into online social networks from the student's point of view, and John-Bauer Graham, head of public services at the Houston Cole Library, for his encouragement.

\section{References and Notes}

1. Angela Reid, "Finally ... the Facebook," The Chanticleer, Sept. 22, 2005, 4 .

2. Facebook.com, http://www.facebook.com/about.php (accessed Dec. 2, 2005).

3. Angus Loten, "The Great Communicator," Inc.Com., June 6, 2006, http://www.inc.com/30under30/zuckerberg.html (accessed Dec. 4, 2005).

4. Adam Lashinsky, "Facebook Stares Down Success," Fortune, Nov. 28, 2005, 4.

5. Michael Amington, "85 Percent of College Students Use Facebook," TestCrunch: Tracking Web 2.0 Company Review on Facebook (Sept. 7, 2005), http:/ / www.techcrunch.com/2005/09/07/ 85-of-college-students-use-facebook (accessed Dec. 2, 2005).

6. http://www.facebook.com/about.php.

7. Facebook us! If you are a registered member of Facebook, do a global search for "Laurie Charnigo" or "Paula BarnettEllis." 
8. Stephen Downes, "Semantic Networks and Social Networks," The Learning Organization 12, no. 5 (2005): 411.

9. Ibid.

10. Tim O'Reilly, "What is Web 2.0?" http://www.oreilly net.com/pub/a/oreilly/tim/news/2005/09/30/what-is-web -20.html (accessed Aug. 6, 2006).

11. http://www.facebook.com/about.php.

12. Angela Provitera McGlynn, "Teaching Millennials, Our Newest Cultural Cohort," The Education Digest 71, no. 4 (2005): 13.

13. Laura Garton, Caroline Haythornthwaite, and Barry Wellman, "Studying Online Social Networks," Journal of Computer Mediated Communication 31, no. 4 (1997).

14. Facebook.com's "About" page archives a collection of college newspaper articles about Facebook: http://www.facebook .com/about.php (accessed Dec. 4, 2005).

15. Brock Read, "Think Before You Share," The Chronicle of Higher Education, Jan. 20, 2006, A38-A41.

16. Ibid., A41.

17. Ibid., A40.

18. Shawn McGuirk, "Facebook on Campus: Understanding the Issues," Magna Web seminar presented live on June 14, 2006. Transcripts available for a fee from Magna Pubs. http://www .magnapubs.com/catalog/cds/598755-1.html (accessed Aug. 2, 2006).

19. Tracy Mitrano, "Thoughts on Facebook" (Apr. 2006) Cornell University of Information Technologies, http://www.cit .cornell.edu/oit/policy/ memos/facebook.html (accessed June 22, 2006).

20. Ibid., "Conclusion."

21. Tabreez Govani and Harriet Pashley, "Student Awareness of the Privacy Implications When Using Facebook," unpublished paper presented at the "Privacy Poster Fair" at the Carnegie Mellon University School of Library and Information Science, Dec. 14, 2005, 9, http://lorrie.cranor.org/courses/fa05/tubzhlp .pdf (accessed Jan. 15, 2006).

22. Ralph Gross and Alessandro Acquisti, "Information Revelation and Privacy in Online Social Networks," paper presentation at the ACM Workshop on Privacy in the Electronic Society, Alexandria, Va., Nov. 7, 2005, 79, http:/ / portal.acm.org/citation .cfm?id=1102214 (accessed Nov. 30, 2005).

23. Frederic Stutzman, "An Evaluation of Identity-Sharing Behavior in Social Network Communities," paper presentation at the iDMAa and IMS Code Conference, Oxford, Ohio, April 6-8, 2006, 3-6, http://www.ibiblio.org/fred/pubs/stutzman _pub4.pdf (accessed May 23, 2006).

24. Gross and Acquisti, "Information Revelation and Privacy in Online Social Networks," 73.

25. "MySpace: Design Anarchy That Works," Business Week, Jan. 2, 2006, 16.
26. Julian Aiken, "Hands off MySpace," American Libraries 37, no. 7 (2006): 33.

27. Ibid.

28. Jessi Hempel and Paula Lehman, "The MySpace Generation," Business Week, Dec. 12, 2005, 94.

29. http://www.facebook.com/about.php.

30. Hempel and Lehman, "The MySpace Generation," 87.

31. The authors created the "Librarians and Facebook" group on Facebook to discuss issues concerning Facebook and librarianship, such as censorship issues, policies, and ideas for connecting with students through Facebook. This is a global group. If you have a Facebook account, we invite you to do a search for "Librarians and Facebook" and join our group.

32. John C. Dvorak, "Academics Get to Work!" PCMagazine Online, http://www.pcmag.com/article2/0,1895,1928970,00 .asp (accessed Feb. 21, 2006).

33. Michael J. Bugeja, "Facing the Facebook," The Chronicle of Higher Education, Jan. 27, 2006, C1-C4; Ibid.

34. Maria Tess Shier, "The Way Technology Changes How We Do What We Do," New Directions for Student Services 112 (Winter 2005): 83-84.

35. Ibid., 84

36. Shier, "The Way Technology Changes How We Do What We Do," 112; J. Duboff, "Poke" Your Prof: Faculty Discovers thefacebook.com," Yale Daily News, Mar. 24, 2005, http://www .yaledailynews.com/article.asp?aid=28845 (accessed Jan. 15, 2006; Mingyang Liu, "Would you Friend Your Professor? Duke Chronicle Online, Feb. 25, 2005, http:/ / www.dukechronicle.com/ media/paper884/news/2005/02/25/News/Would.You.friend .Your.Professors-1472440.shtml?norewrite\&sourcedomain =www.dukechronicle.com (accessed Jan. 15, 2006).

37. Brittany Farb, "Students Can 'Check Out' New Librarian on the Facebook," Student Life (Washington Univ. in St. Louis), Feb. 27, 2006, http://www.studlife.com/home/index.cfm?eve nt=displayArticle\&uStory_id=5914a90d-53b (accessed Feb. 27, 2006).

38. Brian S. Mathews, "Do You Facebook? Networking with Students Online," College \& Research Libraries News 37, no. 5 (2006): 306.

39. Ibid., 307.

40. View the "Houston Cole Library Users Want Answers!" group by doing a search for the group title on Facebook.

41. NCES Compare Academic Libraries, http://nces.ed.gov/ surveys/libraries / compare/PeerVariable.asp (accessed Dec. 2, 2005). The random sample was chosen using the Research Randomizer available online, http://www.randomizer.org/form .htm (accessed Dec. 2, 2005).

42. Michael E. Casey and Laura C. Savastinuk, "Library 2.0," Library Journal 131, no. 14 (2006): 40. 


\section{Appendix A: Survey on the Impact of Facebook on Academic Libraries}

1. Has your institution been added to the Facebook directory?
- Yes
No (skip to questions 10, 11, and 12
Not sure (skip to questions 10, 11, and 12)
I I am not familiar with Facebook (skip all questions and submit)

2. Which best describes your involvement with Facebook?

I have a personal account
My library has an account
$\square$ No involvement

3. Which best describes your observation of student use of library computers to access Facebook?
All the time
Most of the time
Some of the time
Rarely
Dever

4. Has your library added additional equipment such as computers or scanners as a result of Facebook use?
Y Yes
№
No, but we plan to in the future

5. Have patrons complained about other patrons using library computers for Facebook?
प Yes
No
№t sure

6. Has your library had to develop a policy or had to address computer use concerns as a result of Facebook use?
口 Yes
№
․ Not sure

7. If your library provides public access to a scanner, has patron use of scanners increased due to the use of Facebook?

$\begin{array}{ll}\square & \text { Yes } \\ \square & \text { No }\end{array}$
8. Have you assisted students with the library's scanner for Facebook?

प Yes

№

9. If you have provided assistance to students with Facebook, please check all that apply:

ㄱeating accounts

- Scanning photographs or offering advice on where students can access a scanner

- Editing photographs (e.g., resizing photos or use of a photo editor)

U Uploading photographs to Facebook profiles

$\square$ Other

10. Check the responses that best describe your opinion about the responsibilities of librarians in assisting students with Facebook questions and access to the Web site:

- Student use of Facebook on library computers should not be regulated.

L Library resources should not be monopolized with Facebook use.

Computer use for academic purposes should take priority, when needed, over use of Facebook.

- Librarians should help students, when able, with Facebook questions.

- Librarians need to "keep up" with Internet trends, such as Facebook, even if they are not academic in nature.

- There is no connection between librarians, libraries, and Facebook.

- Library computers should be available for Facebook use, but librarians should not feel that they need to assist students with Facebook questions.

11. Would you consider Facebook to be a relevant academic endeavor?
Y Yes
No
Not sure 
12. If you answered "Yes" to question 11, please describe how Facebook could be considered an academic endeavor.

13. Please check all answers that best describe what effect, if any, use of Facebook in the library has had on library services and operations?

- Has increased patron traffic

- Has increased patron use of computers

- Has created computer access problems for patrons

Has created bandwidth problems or slowed down Internet access

- Has generated complaints from other patrons

Annoys library faculty and staff

Interests library faculty and staff

$\square$ Has generated discussion among library faculty and staff about Facebook
14. Is privacy a concern you have about students using Facebook in the library?
$\square$ Yes
口 No
$\square$ Not sure

Please list any observations, concerns, or opinions you have regarding Facebook use in libraries.

\section{Editorial continued from page 3}

extracted the paragraphs from my Palm to my desktop, and saved that document and the TOCs on a Universal Serial Bus (USB) key. Today, I combined them in a new document on my laptop and keyed the remaining paragraphs in my room at an inn on a pier jutting into Commencement Bay in Tacoma on southern Puget Sound. I sought inspiration from the view out my window of the water and the fall color, from Old Crow Medicine Show on my iPod, and from early sixties Beyond the Fringe skits on my Treo.

Fred Kilgour was committed to delivering information to users when and where they wanted it. Libraries must solve that challenge today, and I am confident that we shall. 